\title{
不動産関係判例の動き [15]
}

概 況

今回は判例時報1274 1280号, 判例夕イム ゙ $667 \sim 670$ 号の中から，9件の判決例を選んだ。

1 は物権的請求権に基づく看板徹去請求を認め た事例， 2 は共有者加らの明渡請求を否定した事 例， 3 はマンションの売買契約に扔いて目的物に 隠れた服疵があるとされた事例である。4 は不動 産仲介業者の義務， 5 は店舗の賃貸借契約， 6 は 借家人の義務俰る各事例である。7 は生活公 害，8はダム災害訴訟の各事例である。

\section{1. 物権的請求権}

\section{看板撤去請求控訴事件}

大阪高裁昭和62.11.10判決, 一部変更 ·控訴亲却 (上告), 判夕 670 140

市街地に新築された鉄筋コンクリート造陸屋根 7 階建マンション 1 階の車庫部分の上方にあるパ ラペット部分（外壁部分）飞設置された看板の徹 去 (塗装部分の消去を含む) を請求した事案。

本判決はパラペット部分はその性質及び構造上 共用部分に該当するとし，共用部分たるパラペッ 卜部分の共有特分権から生ずる物権的請求権に基 づき，同請求を認めた。

\section{2. 共 有}

\section{診療所明渡請求事件}

最高裁昭和63. 5. 20判決 (第 2 小法廷), 上告棄却, 判時1277 116

建物（診療所）を共同相続した共有者の一部の 者から共有物の占有使用を承認された第三者に対
不動産判例研究会

してその余の共有者から明渡請求をした事案。

本判決は，共同相続に基づく共有者は自己の特 分に基づいて共有物を占有する権限があり，他の すべての共有者らはその共有者に対して当然には 明渡しを請求するととはできないとする最高裁判 例を引用し, この理は, 共有者の一部の者から共 有物の占有使用を承認された第三者とその余の共 有者との関係にも妥当するとし, 明渡し請求を認 めなかった。判旨は次の通り。

「共有者の一部の者から共有者の協議に基づかな いで共有物を占有使用するてとを承認された第三 者は，その者の占有使用を承認しなかった共有者 に対して共有物を排他的に占有する権限を主張す るととはできないが，現にする占有がてれを承認 した共有者の持分に基づくものと認められる限度 で占有使用する権限を有するので，第三者の占有 使用を承認しなかった共有者は右第三者に対して 当然には共有物の明渡しを請求するてとはできな いと解するのが妥当である。」

\section{3. マンションの売買契約}

\section{売買代金返還請求事件}

大阪地裁昭和61. 12.12判決, 一部認容(確定), 判 夕 $668 \sim 178$

温室で園芸活動を目的とする専用庭付きマンシ ョンの売買に扣いて，契約後に南側隣接地に鉄筋 コンクリート 4 階建の建物が建築され, 日照が阻 害されたため園芸活動が実際上不可能になった場 合に打いて，売買の目的物に隠れた瑕疵があると し，契約金のうち400万円の返還を認めた事例。 
4. 不動産仲介業者の義務

\section{損害賠償請求事件}

東京地裁昭和62.11.27判決, 査却 (控訴), 判時 1280-97

農地法第 5 条による転用許可申請協力請求権が 時效消滅した場合に拈いて，不動産仲介業者には 買主に対する所有権移転登記手続及び引渡が履行 されるように努力すべき義務の不覆行がなかった とした事例。

\section{5. 店舗の賃貸借契約}

\section{建物明渡請求事件}

東京高裁昭和63.4.27判決. 一部変更 (上告), 判 時1274-87

建物 (店舗) 賃貸借契約において, 正当事由の 補完として相当額の立退料を提供するときは解約 申入れによる明渡しを認的てよいとし，(1)本件建 物の必要性が当事者双方にとり営業場所の確保で あるとと，(2)控訴人の今後の営業可能見込年数も さほど長期にわたるものではないこと，(3)热訴人 のこれまでの営業実績, (4)代替建物獲得の因難 性, 双方の必要性の程度を考虑し, 立退料起 2, 500 万円と認め纪事例。

\section{6. 借家人の義務}

\section{家屋明渡等請求事件}

東京北簡裁昭和62.9.22判決, 一部認容 (䃈定), 判夕669-170

建物（東京都北区，木造平屋建居宅）の賃貸借 契約に拈いて，犬猫飼育禁止，石油ストーブ使用 禁止特約に違反して犬 ペキニーズ, 体長30ない し40センチ, 体重 5 キロないし 6 キロ, 愛玩用の いわゆる和座敷犬）を飼育した賃借人に対する家 主加らの明渡請求につき, 信義則上の義務違反は なく, 信頼関係は破壞されていないとして, 請求 を認めなかった事例。

本判決は実質的にみて借家の経済的価值を損な

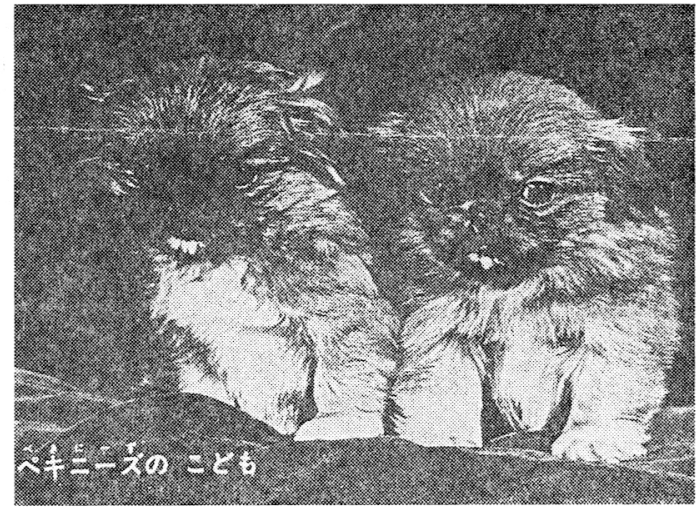

うような不衛生的害悪，火苂等の危険を引き起こ す恐れ，议は近隣の居住者㜆惑となる反社会的 行為があったかどうか学判断のめやすとした。

\section{7. 生活公害}

\section{騒音防止等請求事件}

宋京地裁昭和63.4.25判決, 認容(控訴), 判時127449

被告住居及びその居住敷地内に施いて冷暖房室 外機, 強制換気装置その他音源となる諸機器の使 用にあたり行政規制基準である夜間午後 7 時から 翌朝午前 8 時までの間 40 ホン以上の音量の騒音を 原告住居に侵入させないとと，防音施設の設置等 を認め, かつ, 従前の騒音により原告が被った損 害賠償觉認め记事例。

\section{8. ダム苂害訴訟}

\section{長安口ダム水害訴訟・損害賠償請求事件}

徳島地裁昭和63.6.8判決, 一部認容 (控訴), 判時 1276-3, 判夕669-244

昭和46年 8 月 30 日, 台風23号が徳島県を襲い, 長安口ダム下流の那賀川からの出水により浸水被 害が生じたため，住民64名が，ダムの設置・管理 に瑕疵があったとして，国家賠償法に基づき，国 及び德島県に対し 1 億 5,700 万円の損害賠償を請 求した事例。本判決は, 同ダムには管理上の瑕㾟 が存したと認め, 損害賠償を認好た。 